\title{
A PTOLEMAIC NAOPHOROUS STATUE FROM THE KARNAK CACHETTE (CAIRO JE 36682)
}

\author{
Nashat ALZOHARY \\ Ain Shams University \\ Email: nashat alzohary@art.asu.edu.eg
}

\begin{abstract}
This article presents the Ptolemaic naophorous statue of $\mathrm{Hr}$ son of Ii-m-htp and T3-hy-bi3t. He is holding a naos containing a figure of the god Osiris. This object (JE 36682) is presented in the Cairo Museum. The statue, its inscriptions, and its dating are discussed.

It is today displayed in R 25 W6 B of the Cairo Museum. This statue has not been published hitherto. This statue may be dated to the second half of the $3^{\text {rd }}$ century BC.
\end{abstract}

\section{KEYWORDS}

JE 36682, naophorous statue, Karnak Cachette, Osiris, Ptolemy III

\section{INTRODUCTION}

The statue is one of the many statues found by Legrain in the Karnak Cachette on 20 February 1904. It bears the excavation number K 50, the number JE 36682, and SR. 5/9370. It is today displayed in R 25 W6 B of the Cairo Museum in Tahrir. ${ }^{1}$ It is in near perfect condition, except for the head, which was broken from the torso and was restored. There is also some minor chipping of the nose, the back pillar and the left corner of the base. This statue has not been published hitherto, though it has been mentioned. ${ }^{2}$

\footnotetext{
${ }^{1}$ I am grateful to Mr Mahmoud Elhalwagy, the former Director of the Cairo Museum and Mr Mohamed Aly curator of the Late Period Department, for permitting me to publish this statue.

${ }^{2}$ PM II ${ }^{2}$, 154; De Meulenaere, H., 'La statuette du scribe du roi Pakhnoum', in : $C d E ́$ 72, (1997), 19, n. 12.; Azim, M. and Réveillac, G., Karnak dans l'objectif de Georges Legrain, Paris, (2004), I, 302, II, 222.; De Meulenaere, H., Personnages debout tenant un naos dans la statuaire de la Basse Époque, in: Claes, W. et al. (eds.), Elkab and Beyond. Studies in honour of Luc Limme, OLA 191, Louvain, (2009), 228; Coulon, L., and Jambon, E., L'exploitation scientifique de la Cachette de Karnak, de Georges Legrain à nos jours Essai d'historiographie, in: Coulon, L. (dir.), La Cachette de Karnak Nouvelles perspectives sur les découvertes de Georges Legrain, BdÉ 161, (2016), 122; https://www.ifao.egnet.net/bases/cachette/ck41 (11/11/2021).
} 


\section{DESCRIPTION AND TEXTS}

The statue ${ }^{1}$ is made of limestone, measuring $39.8 \mathrm{~cm}$ in height. Its base is $16.6 \mathrm{~cm}$ in length, $9.8 \mathrm{~cm}$ in width, and $2.6 \mathrm{~cm}$ high. ${ }^{2}$ The figure is represented standing with his left leg advanced, wearing the long wrap-around garment covering the body from chest to ankle. ${ }^{3} \mathrm{~A}$ strap holds it over the left shoulder. The individual presents a naos, which is rectangular, with slightly inclined walls, and a lightly curved roof. ${ }^{4}$ Inside, a standing figure of the god Osiris has been carved half in the round. He is shown in a mummy form, wearing the Atef-crown, holding the flail in his right hand and the crook in his left.

The owner of the statue's head is shaven and egg-shaped, ${ }^{5}$ and the skull's bone structure has not been rendered. As is often the case in Late Egyptian sculpture, the head is slightly turned to the left, both as seen from the front and in relation to the back pillar. His face is not a portrait, but an idealised likeness, with stylised eyes, the contour of which is drawn with a delicate flourish. His eyes are opened as if he was looking skyward. ${ }^{6}$ The rims of the upper lids are sculpted, while cosmetic lines surround the upper lids and partially the lower lids. The rim of the upper eyelid is outlined. In contrast to the full round face, the mouth is small, with thick lips and deeply drilled corners. The lower part of his nose is badly damaged, and it is thin and very straight. The neck, below the small chin, is full. The chin is short, firm and the small ears are remarkably articulate (Figs. I-III).

On the garment, three framed vertical columns of hieroglyphs written from right to left are incised in sunken relief (Figs. IV-V).

\footnotetext{
${ }^{1}$ For the naophorous statues and their significance: Bonnet, H., 'Herkunft und Bedeutung der Naophoren Statue', in: MDAIK 17, (1961), 91-98; van Dijk, J., 'A Ramesside Naophorous Statue from the Teti Pyramid Cemetery', OMRO 64, (1983), 49-58; Klotz, D., 'Replicas of Shu. On the Theological Significance of Naophorous and Theophorous Statues', in: BIFAO 114.2, (2014), 291-337.

${ }^{2}$ In the IFAO database, the height is $60 \mathrm{~cm}$ according to: JE: $60 \mathrm{Ms}$ Legrain-Kuentz (Musée du Caire), II/41: 40.

${ }^{3}$ This garment first introduced into Egypt at the end of the sixth century BC. Bothmer, B. V., Egyptian Sculpture of the Late Period. 700 B.C. to A.D. 100, New York, (1960), 74-76 no. 63.

${ }^{4}$ A variant type shows the naos resting on the hands from the reign of Nectanebo II and later. Bothmer, B. V., Egyptian Sculpture of the Late Period. 700 B.C. to A.D. 100, I49.; Borchardt, L., Statuen und Statuetten von Königen und Privatleuten im Museum zu Kairo, Nr. 1-1294. Vol. III, Berlin, (1930), CG. 715; El-Sayed, R., 'Un document relatif au culte dans le Fayoum à la Basse Epoque. Statue Caire CG.688', in: Supplément au BIFAO 81, (1981), 313-323, 4 pl.; Bianchi, R. S. et. al.(eds.), Cleopatra's Egypt. Age of the Ptolemies, The Brooklyn Museum, 1989, 128, no. 33. Other examples dating to the Ptolemaic Period are mentioned in: Blasius, A., Eine bislang unpublizierte Priesterstatuette aus dem ptolemäischen Panopolis, in: Egberts, A. et. al. (eds.), Perspectives on Panopolis, An Egyptian Town from Alexander The Great to the Arab Conquest, Acts from an International Symposium Held in Leiden on 16, 17 and 18 December 1998, Leiden. Boston. Köln, 2002, 2943; Selim, H., 'The naophorous statue of P3-hr-Hnsw',in: BSAK 9, (2003), 406.

${ }^{5}$ For the egg-heads, so termed because in profile the contours of the shaven heads resemble hens' eggs, see Bianchi, R. S., 'The Egg-Heads: One Type of Generic Portrait from the Egyptian Late Period', in: Römisches Porträt: Wissenschaftliche Zeitscrift der Humboldt-Universität zu Berlin 2/3, (1982), 149-151; Klotz, D., Replicas of Shu. 300.

${ }^{6}$ Apotheosis is represented in Egyptian statuary of the Late and Ptolemaic Periods see: Bothmer, B. V., Apotheosis in Late Egyptian Sculpture, Kêmi XX (1970), 37-48; Metawi, D., 'The Block Statue of $\underline{D} d-h r$ Cairo Museum JE 36668/9', ZÄS 146(1), (2019), 39.
} 


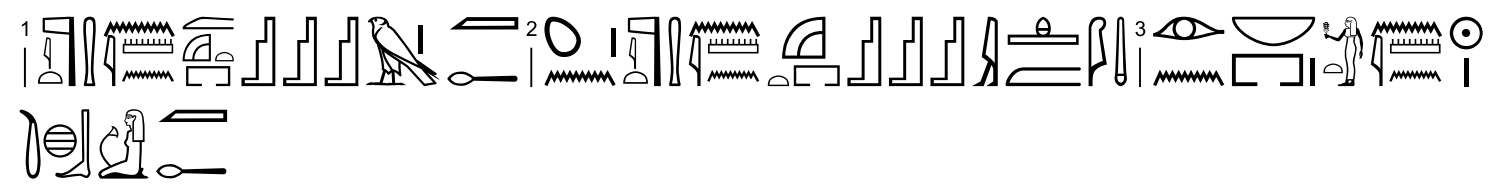

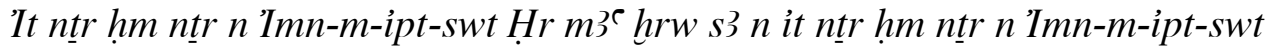

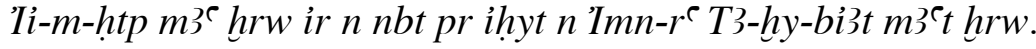

The god's father ${ }^{(\mathrm{a})}$, and the priest of Amun in Karnak, $\mathrm{Hr}^{(\mathrm{b})}$, justified, son of the god's father, and the priest of Amun in Karnak, Ii-m-htp ${ }^{(c)}$, justified, born of the lady of the house, the sistrum player of Amun-Ra ${ }^{(\mathrm{d})}, T 3-h y-b i 3 t^{(\mathrm{e})}$, justified.

(a) For this title, see Habachi, L., Gottesvater, LÄ II (1971), 825-826; Id., God's Fathers and the Role They Played in the History of the First Intermediate Period, ASAE 55 (1958), 167190; Gardiner, A., Ancient Egyptian Onomastica, Oxford 1947, vol. I, 47*; Brunner, H., Der "Gottesvater" als Erzieher des Kronprinzen, ZÄS 86 (1961), 90-100; Kees, H., "Gottesväter" als Priesterklasse, Z̈̈S 86 (1961), 115-125; Selim, H., Three Unpublished Late Period Statues, SAK 32 (2004), 366 n. d.

(b) PN I, 245.18; Lüddeckens, E. et. al. (eds.), Demotisches Namenbuch, vol. I. 2, Wiesbaden 2000, 786-788.

(c) PN I, 9.2; Lüddeckens, E. et. al. (eds.), Demotisches Namenbuch, vol. I. 1, Wiesbaden 2000, 55-56.

(d) For this title, see Albersmeier, S., Untersuchungen zu den Frauenstatuen des Ptolemäischen Ägypten, Mainz am Rhein 2002, 145-146.

(e) De Meulenaere, H., Quatre noms propres de Basse Époque, BIFAO 55 (1955), 147-148; Quack, J. F., Zwei demotische Ausdrücke zur Bezeichnung des Charakters, Z̈̈S 123 (1996), 65; Albersmeier, S., Untersuchungen zu den Frauenstatuen, 150-151; Lüddeckens, E. et. al. (eds.), Demotisches Namenbuch, vol. I. 3, Wiesbaden 2000, 1081.

The back pillar rises from the base in the figure's rear to the upper half of his head. The shape of its top is trapezoidal. ${ }^{1}$ The back pillar is incised with a sunken vertical column of hieroglyphs (facing right), which is surmounted by the sun with rays and the hieroglyphic sign of the sky. These two signs written on the trapezoid could be an epithet of the deceased, read as: $p s \underline{d}-p t$, meaning "Der den Himmel erleuchtet" or $p s \underline{d}-m-p t$ meaning "Der am Himmel leuchtet". ${ }^{2}$

The vertical column of hieroglyphs is (Figs. VI-VII):

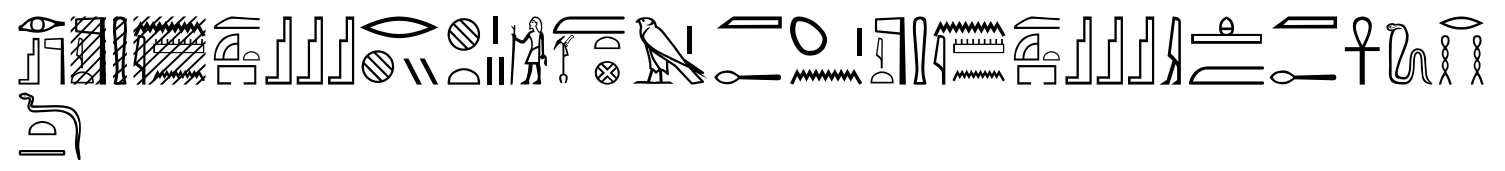

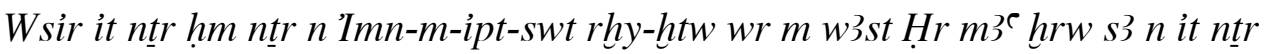

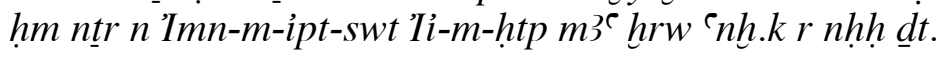

\footnotetext{
${ }^{1}$ This type of top is introduced in the $27^{\text {th }}$ Dynasty and later especially in the Ptolemaic Period. De Meulenaere, H., 'Un général du Delta, gouverneur de la Haute Égypte', in : CdÉ 61, (1986), 204; Id., La statuette du scribe du roi Pakhnoum, 19.

${ }^{2}$ Leitz, Ch., Lexikon der ägyptischen Götter und Götterbezeichnungen, III, OLA 112, Louvain, (2002), 122ab.
}

- 77 - DOI: 10.21608/shedet.2021.207779 
The Osiris, god's father, and the priest of Amun in Karnak, the great wise in Thebes city ${ }^{(a)}, \mathrm{Hr}$, justified, son of the god's father, and the priest of Amun in Karnak, 'Ii-m-htp, justified, may you live ${ }^{(b)}$ forever and ever.

(a) This title means „Großer Gelehrter“, see: Jansen-Winkeln, K., Biographische und religiöse Inschriften der Spätzeit aus dem Ägyptischen Museum Kairo, ÄAT 45, vol. 1, 2001, 168, 307.110-113, 112 n. 1, 114-118, 307, Nrs. 20, 21; Coulon, L., "Les sièges de prêtres d'époque tardive. À propos de trois documents thébains," RdE 57 (2006), 20 n. E; Herbin, F.-R., Books of Breathing and related texts, Catalogue of the Books of the Dead and Other Religious Texts in the British Museum IV (2008), 177, 198.

(b) The writing of the sign $\Omega k$ for the suffix pronoun second person sing. masc. is quite common in Ptolemaic Period. Fairman, H. W., An Introduction to the Study of Ptolemaic Signs and their Values, BIFAO 43 (1945), 78 (195a); Kurth, D., A Ptolemaic Sign-List: Hieroglyphs Used in the Temples of the Graeco-Roman Period of Egypt and their Meanings, Hützel 2010, 110-111 no. 33.

\section{COMMENT AND DATING}

The position and the small size of the naos, as well as the texts, date the statue to the Ptolemaic Period. The position of the owner's hands and fingers wrapped around the bottom edge to carry the naos dates it to the $27^{\text {th }}$ Dynasty onwards. ${ }^{1}$ With time, the balance between the bearer and the naos was lost. Here the naos is small like a naophorous statue in Hanover (Kestner-Museum 1935.200.773), dated to about 150-100 BC, ${ }^{2}$ a Bonn statue (BOSAE Inv. $N r . L 885)$, dated to the $3^{\text {rd }}$ century and first half of the $2^{\text {nd }}$ century $\mathrm{BC},{ }^{3}$ and the Late Ptolemaic Period statue of Cairo (JE 33266). ${ }^{4}$

The garment's type worn by the owner was introduced in the late $26^{\text {th }}$ Dynasty. More significantly, the single shoulder strap did not occur before the Persian Period, becoming common under the Ptolemies. ${ }^{5}$ The inscription on the front of the garment indicates a $3^{\text {rd }}$ century-date like the statue depicted, resembling an Osiris figure in the Cairo Museum (JE 37456), dating to the $3^{\text {rd }}$ century BC, after the reign of Ptolemy III. ${ }^{6}$ Another parallel is a $2^{\text {nd }}$ century naophorous statue of Cairo (JE 37328), ${ }^{7}$ and a $1^{\text {st }}$ century BC naophorous statue of Cairo (JE 37376). ${ }^{8}$ The most distinctive feature of this statue is his face and shaven head: ${ }^{9}$ the rounded eyes, large ears, fleshy cheeks, the nose, and the small mouth, with rather thick

\footnotetext{
${ }^{1}$ Holding the naos between the hands was introduced since the $30^{\text {th }}$ Dynasty onwards. De Meulenaere, H., 'Une statue de prêtre héliopolitain', in: BIFAO 61, (1962), 40.

${ }^{2}$ Bothmer, B. V., Egyptian Sculpture of the Late Period, 148-149; Bianchi, R. S., et. al. (eds.), Cleopatra's Egypt. Age of the Ptolemies, The Brooklyn Museum, Brooklyn, (1988), 128 (cat.33).

${ }^{3}$ Blasius, A., Eine bislang unpublizierte Priesterstatuette, 29-43.

${ }^{4}$ Biankhi, R. S., 'The Striding Draped Male Figure of Ptolemaic Egypt', in: Maehler, H., et. al. (eds.), Das ptolemäische Ägypten: Akten des internationalen Symposions 27.-29. september 1976 in Berlin, Mainz am Rhein, (1978), 95 ff., fig. 54.

${ }^{5}$ Klotz, D., 'A Good Burial in the West: Four Late Period Theban Statues in American Collections', in: Coulon L. (ed.), La Cachette de Karnak. Nouvelles perspectives sur les découvertes de G. Legrain, BdÉ 161, (2016), 435, n. 14.

${ }^{6}$ De Meulenaere, H., La statuette du scribe du roi Pakhnoum, 17, 19.

7 Jansen-Winkeln, K., Biographische und religiöse Inschriften der Spätzeit aus dem Ägyptischen Museum Kairo, ÄAT 45, (2001), 258-266, Nr.41; Perdu, O., Les statues privées de la fin de l'Égypte pharaonique (1069 av. J.-C - 395 apr. J.-C.), vol. I - Hommes, Paris, (2012), 305, n. 57; 307, n. 120; 445, n. 25.

${ }^{8}$ El-Sayed, R., 'À la recherche des statues inédites de la Cachette de Karnak au Musée du Caire (IV)', in : $A S A E$ 81, (2007), 53-58, 73-74 (doc. 11); Perdu, O., Les statues privées, 265, n. 6; 391, n. 19; 445, n. 39.

${ }^{9}$ Bothmer, B. V., Egyptian Sculpture of the Late Period, 65.
} 
lips and deeply drilled corners. The closest parallel is the head of the prophet of Horemheb (Academy of the New Church Museum, Bryn Athyn, Pa), which Bothmer dated to 280-250 BC. ${ }^{1}$ Other comparisons include the statue of Pakhnoum in the Cairo Museum (JE 37456), notably its garment and the back pillar top, as well as the naophorous statue of Bonn (BOSAE Inv. Nr. L885), and the Cairo naophorous statue (JE 37328). As a result, the dating of this statue is specified to the second half of the $3^{\text {rd }}$ century BC.

Based on the inscriptions described above, the family genealogy of the subject is as follows:

$$
\begin{aligned}
& \text { Ii-m-htp (father) } \quad=\quad T 3-h y-b i 3 t \text { (mother) }
\end{aligned}
$$

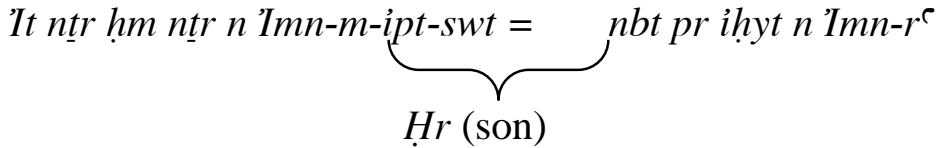

It ntr hm ntrr n Imn-m-ipt-swt $t^{2}$ rhy-hntw wr $m$ w3st

\footnotetext{
${ }^{1}$ Bothmer, B. V., Egyptian Sculpture of the Late Period, 127-128, No. 99.

${ }^{2}$ This title is more common in Ptolemaic Thebes, see: Birk, R., 'Genormt? Zur überregionalen Normierung von priesterlichen Epitheta in der Ptolemäerzeit', in: Ullmann, M. (ed.), 10. Ägyptologische Tempeltagung: Ägyptische Tempel zwischen Normierung und Individualität, München, 29.—31. August 2014, Wiesbaden, (2016), 29-30.
} 


\section{BIBLIOGRAPHY}

1- Albersmeier, S., Untersuchungen zu den Frauenstatuen des Ptolemäischen Ägypten, Mainz am Rhein, (2002).

2- Azim, M. and Réveillac, G., Karnak dans l'objectif de Georges Legrain: catalogue raisonné des archives photographiques du premier directeur des travaux de Karnak de 1895 à 1917, I, II, Paris, (2004).

3- Biankhi, R. S., 'The Striding Draped Male Figure of Ptolemaic Egypt', in: Maehler, H. and V. M. Strocka (eds.), Das ptolemäische Ägypten: Akten des internationalen Symposions 27.-29. september 1976 in Berlin, Mainz am Rhein, (1978), 95-102.

4- -------, 'The Egg-Heads: One Type of Generic Portrait from the Egyptian Late Period', in: Römisches Porträt: Wissenschaftliche Zeitschrift der Humboldt-Universität zu Berlin 2/3, (1982), 149-151.

5- Bianchi, R. S. et. al.(eds.), Cleopatra's Egypt. Age of the Ptolemies, The Brooklyn Museum, (1989).

6- Birk, R., Genormt., 'Zur überregionalen Normierung von priesterlichen Epitheta in der Ptolemäerzeit', in: Ullmann, M. (ed.),. Ägyptologische Tempeltagung: Ägyptische Tempel zwischen Normierung und Individualität, München, 29.-31. August 2014, Wiesbaden, (2016), 17-35.

7- Blasius, A., 'Eine bislang unpublizierte Priesterstatuette aus dem ptolemäischen Panopolis', in: Egberts, A. et. al. (eds.), Perspectives on Panopolis, An Egyptian Town from Alexander The Great to the Arab Conquest, Acts from an International Symposium Held in Leiden on 16, 17 and 18 December 1998, Leiden, Boston, Köln, (2002), 29-43.

8- Bonnet, H., 'Herkunft und Bedeutung der Naophoren Statue', in: MDAIK 17, (1961), 91-98.

9- Borchardt, L., Statuen und Statuetten von Königen und Privatleuten im Museum zu Kairo, Nr. 11294. Vol. III, Berlin, (1930).

10- Bothmer, B. V., Egyptian Sculpture of the Late Period. 700 B.C. to A.D. 100, New York, (1960).

11- --- 'Apotheosis in Late Egyptian Sculpture', in: Kêmi XX, (1970), 37-48.

12- Brunner, H., 'Der "Gottesvater" als Erzieher des Kronprinzen', in : Z̈̈S 86, (1961), 90-100.

13- Coulon, L., 'Les sièges de prêtres d'époque tardive. À propos de trois documents thébains', in : RdE 57, (2006), 1-45.

14- Coulon, L., and Jambon, E., 'L'exploitation scientifique de la Cachette de Karnak, de Georges Legrain à nos jours Essai d'historiographie', in: Coulon, L. (dir.), La Cachette de Karnak Nouvelles perspectives sur les découvertes de Georges Legrain, Bd'É 161, (2016), 89-129.

15- De Meulenaere, H., 'Quatre noms propres de basse époque ', in : BIFAO 55, (1955), 141-148.

16- -------, 'Une statue de prêtre héliopolitain ', in : BIFAO 61, (1961), 29-42.

17- --------------, 'Un général du Delta, gouverneur de la Haute Égypte', in : $C d E ́$ 61, (1986), 203-210.

18- ------o 'La statuette du scribe du roi Pakhnoum', in : CdÉ 72, (1997), 17-24.

19- -------, 'Personnages debout tenant un naos dans la statuaire de la Basse Époque', in: Claes, W. et. al. (eds.), Elkab and Beyond. Studies in honour of Luc Limme, OLA 191, Louvain, (2009), 223-231.

20- van Dijk, J., 'A Ramesside Naophorous Statue from the Teti Pyramid Cemetery', in: OMRO 64, (1983), 49-58.

21- El-Sayed, R., 'Un document relatif au culte dans le Fayoum à la Basse Epoque. Statue Caire CG.688', in: Supplément au BIFAO 81, (1981), 313-323.

22- --------, 'À la recherche des statues inédites de la Cachette de Karnak au Musée du Caire (IV)', in : ASAE 81, (2007), 53-100.

23- Fairman, H. W., 'An Introduction to the Study of Ptolemaic Signs and their Values',in: BIFAO 43 (1945), 51-138.

24- Gardiner, A., Ancient Egyptian Onomastica, Oxford, 1947.

25- Habachi, L., 'God's Fathers and the Role They Played in the History of the First Intermediate Period', in: ASAE 55, (1958), 167-190.

26- --------, 'Gottesvater', in: $L \ddot{A}$ II, (1971), 825-826. 
27- Herbin, F.-R., Books of Breathing and related texts, Catalogue of the Books of the Dead and Other Religious Texts in the British Museum IV, London, (2008).

28- Jansen-Winkeln, K., Biographische und religiöse Inschriften der Spätzeit aus dem Ägyptischen Museum Kairo, ÄAT 45, (2001).

29- Kees, H., “'Gottesväter” als Priesterklasse', ZÄS 86, (1961), 115-125.

30- Klotz, D., 'Replicas of Shu. On the Theological Significance of Naophorous and Theophorous Statues', in: BIFAO 114.2, (2014), 291-337.

31- -------, 'A Good Burial in the West: Four Late Period Theban Statues in American Collections', in: Coulon L. (ed.), La Cachette de Karnak. Nouvelles perspectives sur les découvertes de G. Legrain, Bd'É 161, (2016), 433-464.

32- Kurth, D., A Ptolemaic Sign-List: Hieroglyphs Used in the Temples of the Graeco-Roman Period of Egypt and their Meanings, Hützel, (2010).

33- Leitz, Ch., Lexikon der ägyptischen Götter und Götterbezeichnungen, III, OLA 112, Louvain, (2002).

34- Lüddeckens, E. et. al. (eds.), Demotisches Namenbuch, vols. I/2, 3 Wiesbaden, (2000).

35- Metawi, D., 'The Block Statue of D $d$ - $h r$ Cairo Museum JE 36668/9', ZÄS 146/1, (2019), 3641.

36- Perdu, O., Les statues privées de la fin de l'Égypte pharaonique (1069 av. J.-C - 395 apr. J.-C.), vol. I - Hommes, Paris, (2012).

37- PM $\mathrm{II}^{2}$ : Porter, B., and Moss, R. L., Topographical Bibliography of Ancient Egyptian Hieroglyphic Texts, Reliefs and Paintings, II, Oxford, (1972).

38- PN I: Ranke, H., Die ägyptischen Personennamen, I, Glückstadt, (1935).

39- Quack, J. F., 'Zwei demotische Ausdrücke zur Bezeichnung des Charakters', ZÄS 123, (1996), 62-69.

40- Selim, H.,'The naophorous statue of P3-hr-Hnsw in Cairo Museum JE 37993bis from Karnak Cachette, Excavation Number K.585', BSAK 9, (2003), 399-407.

41 - -------, 'Three Unpublished Late Period Statues', SAK 32, (2004), 363-378.

42- https://www.ifao.egnet.net/bases/cachette/ck41 (11/11/2021). 


\section{PLATES}

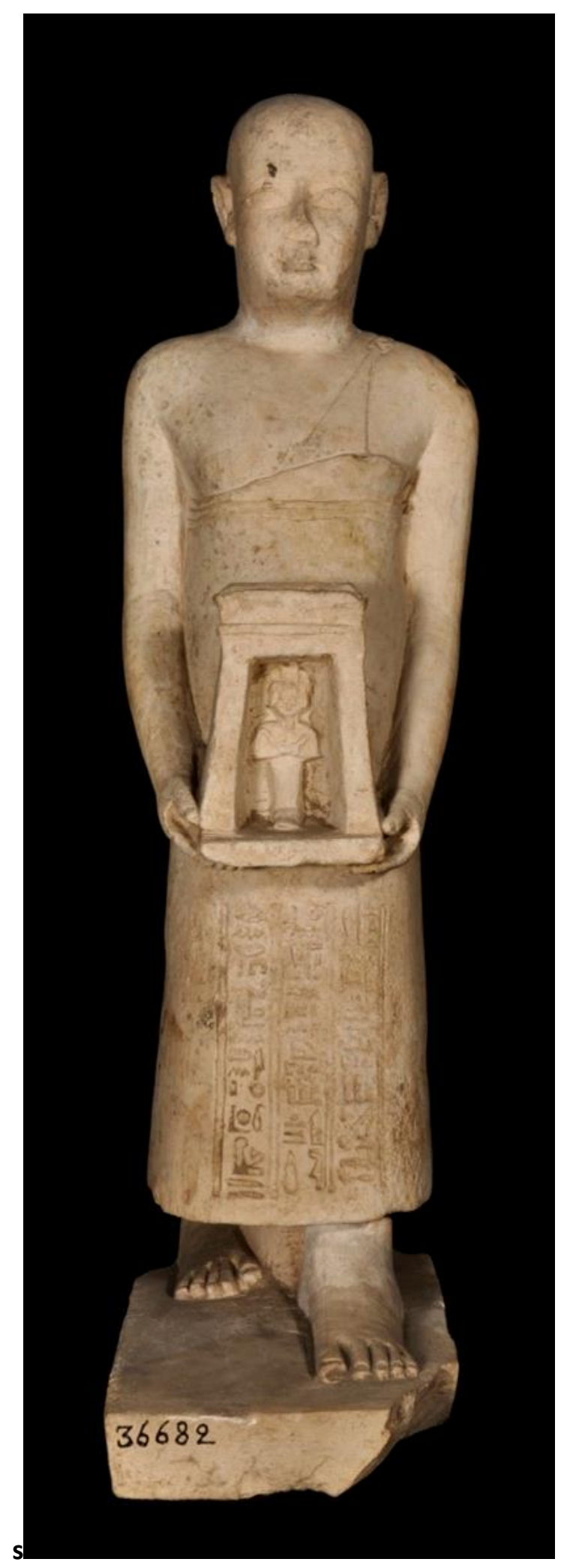

Fig. I: A Ptolemaic naophorous Statue (Cairo JE 36682). 


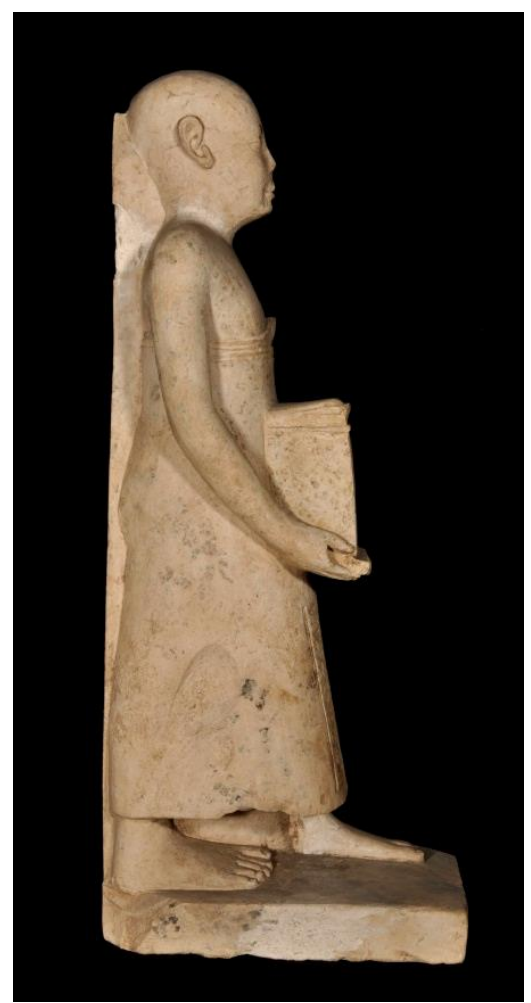

Fig. II: Right side of a Ptolemaic naophorous Statue (Cairo JE 36682).

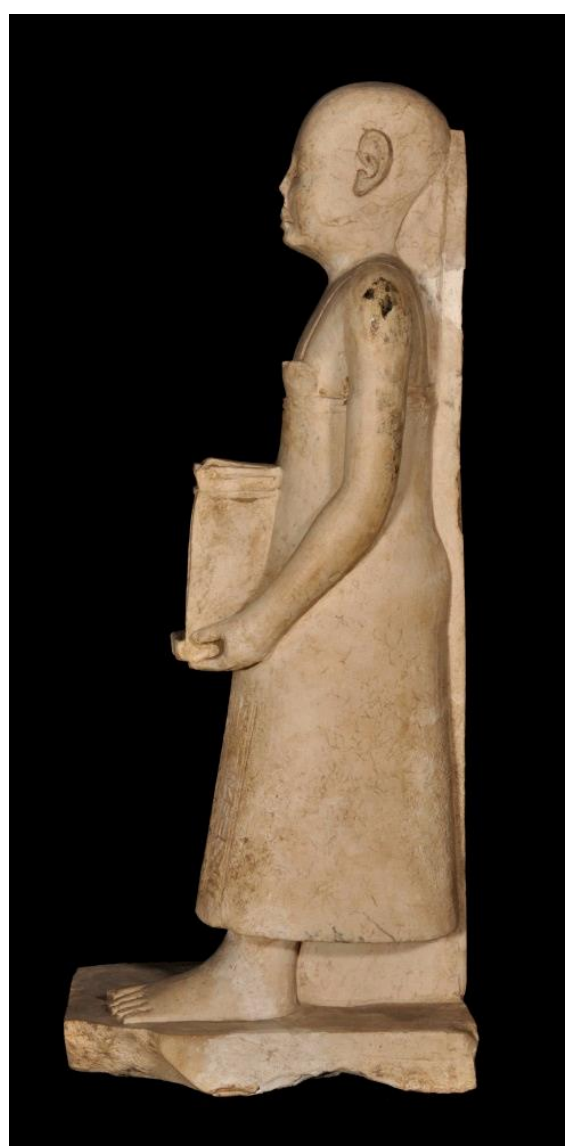

Fig. III: Left side of a Ptolemaic naophorous Statue (Cairo JE 36682). 


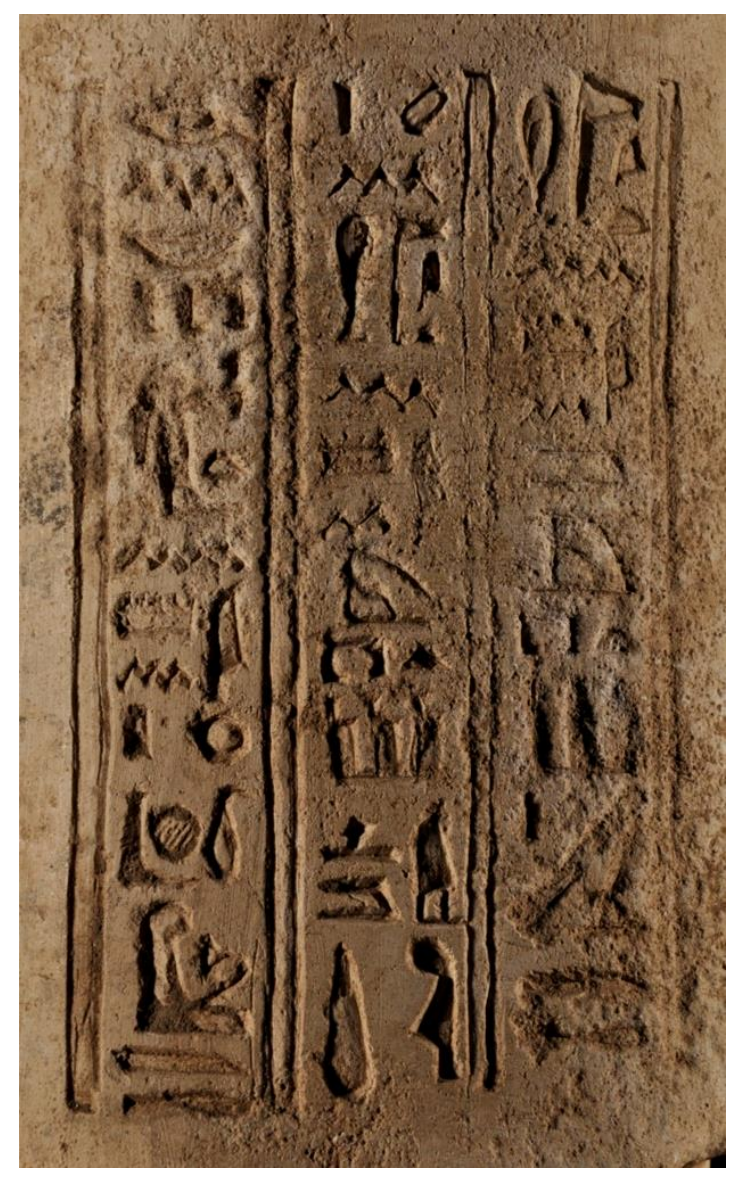

Fig. IV: Detail of a Ptolemaic naophorous Statue (Cairo JE 36682).

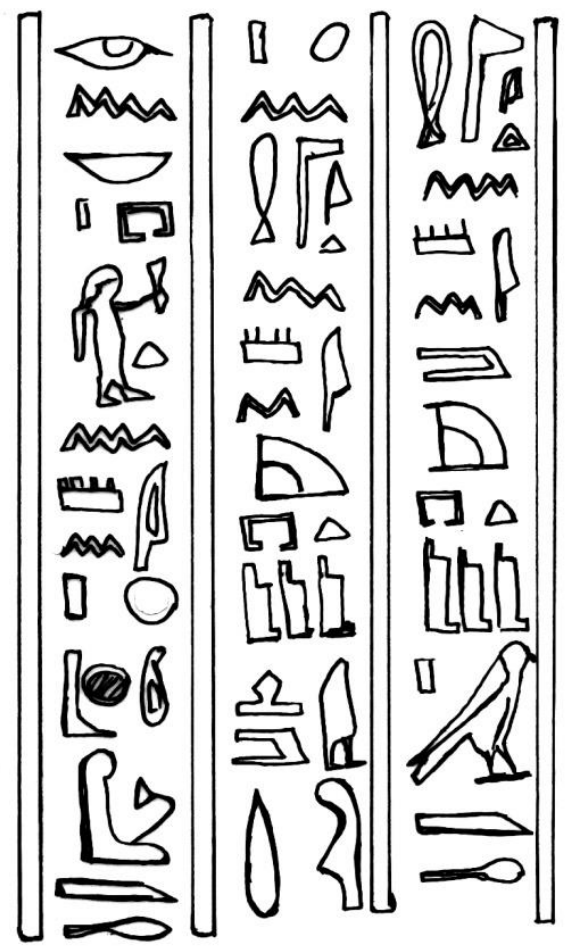

Fig. V: Line drawing of the main text on the front side of the statue. 


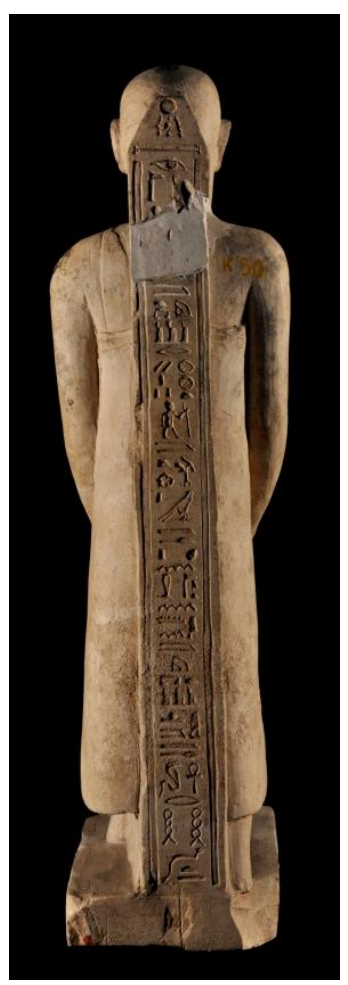

Fig. VI: Back side of a Ptolemaic naophorous Statue (Cairo JE 36682).

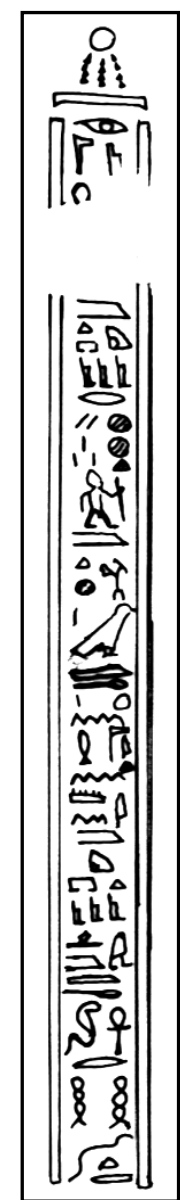

Fig. VII: Line drawing of the text on the back-pillar of the statue. 